\title{
Hormophysa cuneiformis (Phaeophyta: Fucales) in Micronesia ${ }^{1}$
}

\author{
Roy T. Tsuda ${ }^{2}$
}

\begin{abstract}
Specimens of Hormophysa cuneiformis (J. Gmelin) P. Silva, collected by R. E. DeWreede in July 1968 and by the author in January 1971 from Palau, are documented for the first time and represent the first collections of a member of the family Cystoseiraceae from Micronesia. A single specimen $6 \mathrm{~cm}$ tall of $H$. cuneiformis was collected $4.5 \mathrm{yr}$ later in July 1975 on a reef bench tide pool at Pagan Island in the Northern Mariana Islands by R. Rechebei and was reported in a floristic account of the Chlorophyta and Phaeophyta of the Northern Mariana Islands in 1977. Specimens of this large and conspicuous brown alga have not been reported previously from Palau nor other islands in Micronesia.
\end{abstract}

Numerous collections of marine benthic algae and sea grasses were made by me during the late 1960s and early and mid-1970s throughout Micronesia. Tsuda and Tobias (1977) reported a collection of Hormophysa cuneiformis (J. Gmelin) P. Silva, as H. triquetra (C. Agardh) Kützing, from the Northern Mariana Islands. The specimen $(6 \mathrm{~cm}$ tall $)$ collected by Ramon Rechebei in July 1975 on a reef bench tide pool at Pagan Island represented the first report of a member of the family Cystoseiraceae (order Fucales) from Micronesia (Figure 1). Previous to the 1977 publication, the genera Sargassum and Turbinaria in the family Sargassaceae were the only members of the order Fucales reported in the literature (see Tsuda and Wray 1977) from the Micronesian region.

This collection, however, did not represent the first of this taxon for Micronesia because two earlier collections had been made in Palau to the southwest of the Mariana Islands by Robert E. DeWreede in July 1968 and by me in January 1971. The specimens were not reported at that time because new algal records were the normal situation and not unusual. After $32 \mathrm{yr}$, no additional col-

\footnotetext{
${ }^{1}$ Contribution No. 545, University of Guam Marine Laboratory. Manuscript accepted 11 April 2003.

${ }^{2}$ Marine Laboratory, University of Guam, UOG Station, Mangilao, Guam 96923.
}

Pacific Science (2004), vol. 58, no. 1:23-26

(C) 2004 by University of Hawai'i Press

All rights reserved lections of the large and conspicuous Hormophysa have been reported from Palau (Tsuda 2002) nor from any other island groups in Micronesia. Members of the Cystoseiraceae are generally temperate species, except for Hormophysa. Ohba (1996) reported on 164 taxa collected between 18 and 29 October 1995 in the southern sector of Palau (i.e., between Oreor [Koror] and Beliliou Island [Peleliu]) and included Hormophysa among the genera of marine benthic algae that he expected, but did not find, in Palau.

This paper documents the 1968 and 1971 collections of Hormophys cuneiformis from the Palau Archipelago.

\section{Hormophysa cuneiformis (J. Gmelin) P. Silva in} Silva et al., 1987

SYNONYMS (see Silva et al. 1987, 1996): Fucus cuneiformis J. Gmelin, Cystoseira articulata J. Agardh and Hormophysa articulata Kützing, Cystoseira prolifera J. Agardh and Hormophysa prolifera (J. Agardh) O. C. Schmidt, Hormophysa latifrons Kützing, Cystoseira triquetra C. Agardh and Hormophysa triquetra (C. Agardh) Kützing.

DESCRIPTION OF PALAU SPECIMENS: The dried specimen in Figure 2 (RDW 42a) is 20 $\mathrm{cm}$ tall, light brown, and resembles the photographs of this species as depicted in Okamura (1913) and Papenfuss (1967). The short holdfast is $7 \mathrm{~mm}$ in diam. and gives rise to five terete axes, less than $1 \mathrm{~mm}$ in diam. and up to $2 \mathrm{~cm}$ long. The axes then develop threesided, serrated winged blades, each up to 4 


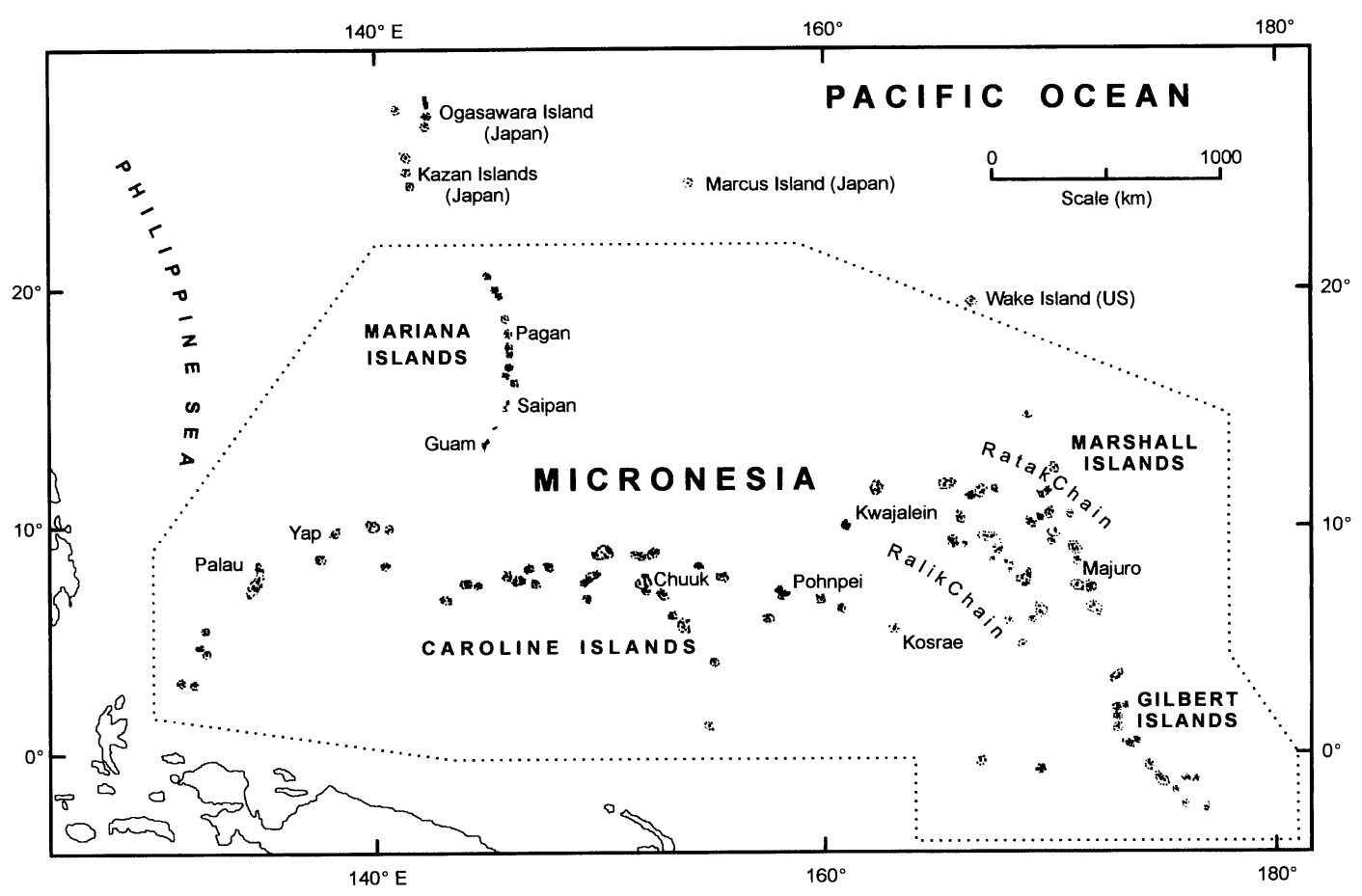

Figure 1. Map of Micronesia (adapted from Karolle 1993).

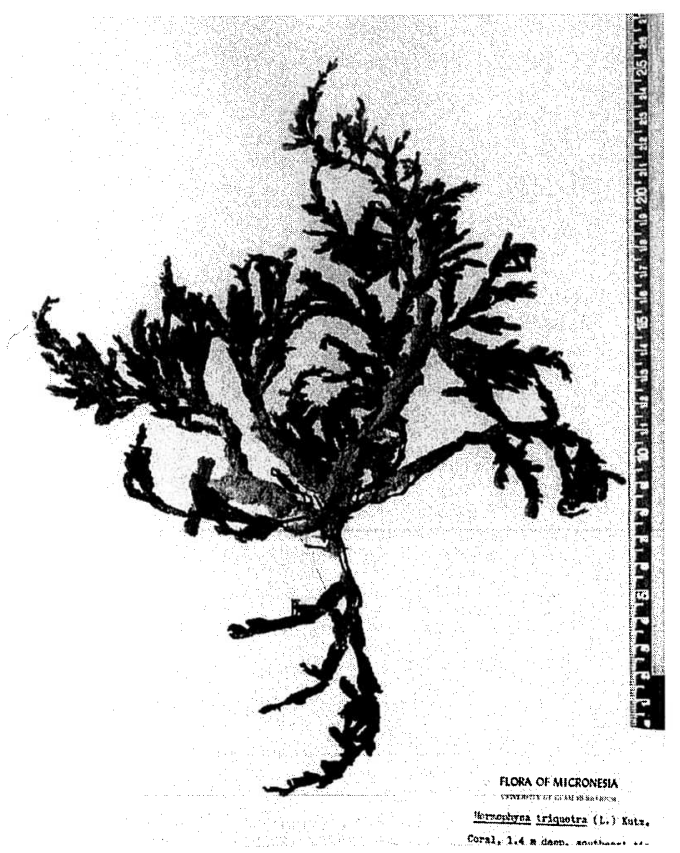

FIgURE 2. Hormophysa cuneiformis, RDW 42a, coral reef, Ngeruktabel, Palau. Vertical dimension, $28 \mathrm{~cm}$. $\mathrm{mm}$ wide. Lateral branches arise from the rachis (i.e., the former axes). Few elliptical vesicles, $3-4 \mathrm{~mm}$ long and $1-1.5 \mathrm{~mm}$ diam., are embedded within the former rachis. Conceptacles are abundant on the narrower wings of the ultimate and subultimate branches.

Herbarium sheet RT 4082 (Figure 3) consists of a single specimen of $H$. cuneiformis that is $24 \mathrm{~cm}$ tall and dark brown, with older branches covered with epiphytic calcareous Fania capillacea Harvey and Hydrolithon farinosum (Lamouroux) Penrose \& Y. M. Chamberlain. Approximately 30 terete axes, up to $5.5 \mathrm{~cm}$ long, arise from the $13-\mathrm{mm}$ wide holdfast, which then transitions to either two-sided (i.e., Sargassum-like) or three-sided (i.e., Hormophysa-like) winged blades, up to 5 $\mathrm{mm}$ wide. Few vesicles are present; however, conceptacles are numerous on the blades of the ultimate branches. Hideo Ohba (pers. comm., 29 November 2002) confirmed that specimens of $H$. cuneiformis from Okinawa are similar to specimen RT 4082.

Herbarium sheet RT 4089 consists of 


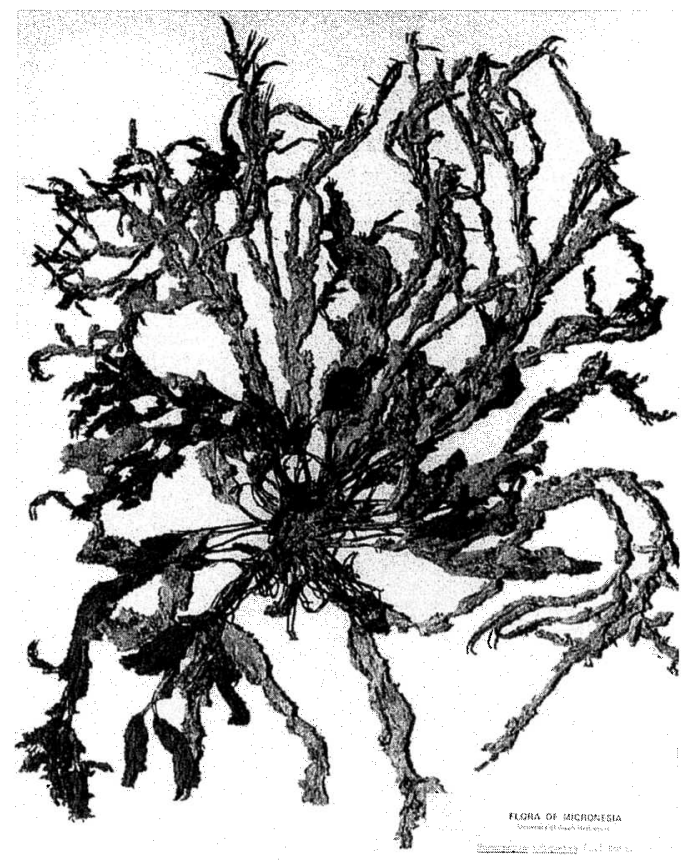

FIgURE 3. Hormophysa cuneiformis, RT 4082, patch reef, north of Oreor, Palau. Vertical dimension, $35 \mathrm{~cm}$.

three dried, straggly specimens, up to $15 \mathrm{~cm}$ long, which possess few vesicles.

PALAU SPECIMENS EXAMINED: RDW 42a, coral reef, $1.4 \mathrm{~m}$ deep, southeast tip of southern E-W arm of Ngeruktabel (Urukthapel), 4 July 1968, coll. R. E. DeWreede; RT 4082, patch reef, 1-2 $\mathrm{m}$ deep, $1.5 \mathrm{~km}$ north of Oreor (Koror), 1 January 1971, coll. R. T. Tsuda; RT 4089, patch reef, west of Arumaten Point, west coast of Babeldaob (Babelthuap), 2 January 1971, coll. R. T. Tsuda.

PACIFIC Distribution: Palau reported herein; Northern Mariana Islands (Tsuda and Tobias 1977 as Hormophysa triquetra); Tonga (Papenfuss 1967 as H. triquetra); Tubuai, French Polynesia (Denizot 1980); Solomon Islands (Womersley and Bailey 1970 as $H$. triquetra); New Caledonia (Garrigue 1987 as H. triquetra); Papua New Guinea (WeberVan Bosse 1913 as Cystoseira prolifera); Indonesia (Weber-Van Bosse 1913 as C. prolifera; Papenfuss 1967 as H. triquetra); the Philippines (Silva et al. 1987); Ryukyu Islands
(Okamura 1913 as Cystoseira articulata, and Segawa and Kamura 1960 as C. prolifera); Australia (see Silva et al. 1996).

NOMENCLATURE AND TAXONOMY: The complicated nomenclatural history of this species was discussed by Papenfuss (1967) and updated 20 yr later by Silva et al. (1987). In a study of the morphology and taxonomy of the genus Cystophora, Womersley (1964:65) included a key to the 16 genera within the family Cystoseiraceae and distinguished the genus Hormophysa from other genera by the 'conceptacles scattered on 'wings' of the axes; axes usually triquetrous, containing ovoid vesicles, with coarsely dentate wings."

The most comprehensive taxonomic study of Hormophysa was conducted by Papenfuss (1967) on materials from East Africa, Australia, the Red Sea, New Caledonia, Tonga, the South China Sea, the Philippines, and the Ryukyu Islands. He described the development of the vesicles embedded within the winged axes on the ultimate and subultimate branches; the vesicles are elliptical in longitudinal section and three-edged or triangular in cross section. A vesicle is developed by the breakdown of the rachis and adjacent wings, and subsequent inflation of the space. Papenfuss (1967) also reported that the flask-shaped conceptacles on both sides of the wings are bisexual, containing both oogonia and clusters of antheridia. The genus Hormophysa lacks receptacles, which are observed prominently in fertile Sargassum and Turbinaria species.

\section{ACKNOWLEDGMENTS}

My appreciation to Robert E. DeWreede, University of British Columbia, for the specimen of Hormophysa cuneiformis collected during our respective graduate student years, and to Barry D. Smith, University of Guam Marine Laboratory, for the map of Micronesia. I acknowledge two anonymous reviewers for providing useful suggestions toward the improvement of the paper.

\section{Literature Cited}

Denizot, M. 1980. La vègètation algale de Tubuai. Cah. Indo Pac. 2:242-254. 
Garrigue, C. 1987. Les macrophytes benthiques du lagon sud-ouest de la NouvelleCaledonie. (Cartes des principaux groupements). Rapport scientifique et technique, No. 46. ORSTOM, Noumea. 122 pp.

Karolle, B. G. 1993. Atlas of Micronesia. 2nd ed. Bess Press, Honolulu.

Ohba, H. 1996. The benthic marine flora of the Palau Islands (WCI): New records, missing records and implications for biodiversity. Pages 45-54 in T. Aoyama, ed. Progress report of the 1995 survey of the research project "Man and the Environment in Micronesia." Kagoshima Univ., Res. Cent. South Pac., Occas. Pap. No. 30.

Okamura, K. 1913. Icones of Japanese algae. Tokyo. 3:1-77, pls. 101-120.

Papenfuss, G. F. 1967. The history, morphology and taxonomy of Hormophysa (Fucales: Cystoseiraceae). Phytomorphology 17:42-47.

Segawa, S., and S. Kamura. 1960. Marine flora of Ryukyu Islands. University of the Ryukyus Extension Service. 72 pp.

Silva, P. C., E. G. Meñez, and R. L. Moe. 1987. Catalog of the benthic marine algae of the Philippines. Smithson. Contrib. Mar. Sci. 27:1-179.
Silva, P. C., P. W. Basson, and R. L. Moe. 1996. Catalogue of the benthic marine algae of the Indian Ocean. University of California Press, Berkeley.

Tsuda, R. T. 2002. Checklist of the marine benthic algae from the Palau Archipelago based on past references. Palau International Coral Reef Center, No. 02-019. 21 pp.

Tsuda, R. T., and W. J. Tobias. 1977. Marine benthic algae from the Northern Mariana Islands, Chlorophyta and Phaeophyta. Bull. Jpn. Soc. Phycol. 25:19-24.

Tsuda, R. T., and F. O. Wray. 1977. Bibliography of marine benthic algae in $\mathrm{Mi}$ cronesia. Micronesica 13:85-120.

Weber-Van Bosse, A. 1913. Liste des algues du Siboga. I. Myxophyceae, Chlorophyceae, Phaeophyceae. Siboga-Exped. Monogr. 59a. Leiden.

Womersley, H. B. S. 1964. The morphology and taxonomy of Cystophora and related genera (Phaeophyta). Aust. J. Bot. 12:53110.

Womersley, H. B. S., and A. Bailey. 1970. Marine algae of the Solomon Islands. Philos. Trans. R. Soc. Lond. B. Biol. Sci. 259:257-352. 